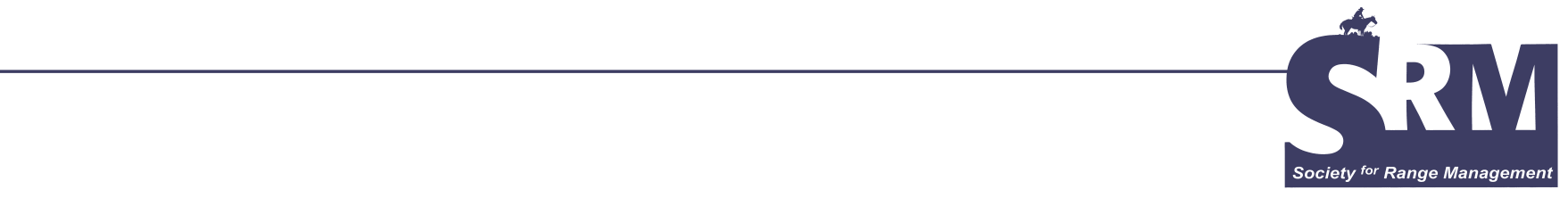

\title{
Seventh in a Series: Insight From SRM's Charter Members
}

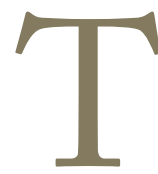
he Society for Range Management (SRM) History Committee has conducted interviews with many of the Society's charter members to capture their perspective of events leading to and subsequent to the formation of the American Society of Range Management in 1947-1948. Interviews from several of these individuals will be shared for today's SRM members to enjoy and learn from.

\section{SRM Charter Member - J. Kent Giles \\ Editor's Note: Art Tait interviewed J. Kent Giles in January 2003. Kent lives at 541 S 300 W, Cedar City, UT 84720.}

The reason I am living in Cedar City is that this was the last place I worked with the Bureau of Land Management (BLM). When it came time to retire, I decided this was a better place to live than up north where we owned some property.

In the summer of 1947, when the ASRM began, I worked for the Forest Service on the Teton National Forest on the Jackson Ranger District in Jackson, Wyoming, with Doug Wadsworth. Doug was a good friend of mine from the Granddaddy Lakes District in Utah. I was raised in Hanna, Utah, and he was the ranger there. Doug wanted me to come and work for him in Wyoming, because I had previously done range work for him on the Granddaddy District. That winter I went back to school at Utah State for my 4th winter. In the spring of 1948 I went back to Jackson, Wyoming. Doug was in charge of a bug job there and he wanted me to leave school a little early and come up and take over the ranger district for a while since he was involved in a bug job that covered more than 1 district.

I spent the summer there. Actually, I hadn't graduated. There were some elective classes that Dr Stoddart thought I should take. I had more hours than I needed but I didn't graduate. I had taken the civil service exam and the Forest Service had told me they would give me a permanent job. I had turned down a job with the Soil Conservation Service, but it went clear through the summer and into the fall, and the Forest Service said when my name got back from the Soil Conservation Service, they would pick it up. In the meantime, I got an offer from the BLM in Utah. I came to Utah, and interviewed there, and talked again with the Forest Service and they couldn't at that moment give me a job, so I went with the BLM. I started with the BLM in Nephi, Utah, in 1948. It was a district office then, but there hasn't been one there since 1952 .

In my last year at Utah State, I was working toward a degree in range management because I felt that was the field I wanted to go into. There was more opportunity there and more along the line that I was interested in. So I decided to get a degree in range management. I was influenced some by Doug Wadsworth, who had encouraged me to go to college. I had worked for him for 6 years before I decided to go to college.

That winter they were having this meeting to talk about the formation of this Society of Range Management in Salt Lake. Some of us as students went with Dr Cook to that meeting. Drs Cook, Stoddart, and Smith were all professors there. Of course, Dr Stoddart was head of the Range Management part of the school. We went down to that meeting and there they discussed the formation of the Society. I don't remember the details of their coming up with leadership. One fellow I remember well was Joe Pechanec. I remember him giving quite a talk. He was with the Forest Service in California at that time. Dr Stoddart also had some things to say. I was part of the meeting and I really enjoyed the things that were said. They brought out the importance of good range management and the fact that not only public land, but the private lands as well, were better suited as rangelands for livestock grazing as well as for wildlife. One point was brought out that was really important: these lands should be managed properly so grazing could continue. We 
need to maintain the lands and improve them so people can continually use them. This appealed to me because I had been raised on a ranch and had run sheep and cattle and had been raised with livestock all my life and I knew a little bit about how important it was to have forage for them. To do this, the ASRM was organized.

In response to my expectations of SRM then and whether they have been fulfilled, I feel they tried. I am not sure we were as effective as we could have been, but I am sure members of the Society in their own field locations did a lot toward accomplishing that.

I started working in Nephi, Utah, on the Nephi District for the BLM in December 1948. About that same time about a year later, I got a letter in the mail telling me they didn't have any more money in range at that time, so I was supposed to report to the Salt Lake office as a field examiner in the Utah-Colorado region the next Monday, which I did. I worked from November 1949 to February 1951 as a field examiner, which involved examining the many different lands cases. When I started school, I was thinking of becoming a forest ranger. But during the time I was at Utah State, the BLM was organized and brought together the old Land Office and the Grazing Service. So this put me into the land office of the Bureau in the fall of 1949 until 1951 working on all types of lands cases throughout Utah and Colorado. In 1951, I went back to Nephi where there was a vacancy. The range manager who was head of the office had been transferred and they hadn't been able to fill that job. I was transferred back to Nephi and was there from 1951 to June 1952, when I was selected as the District Manager for the Salt Lake District. I worked there from 1952 to 1961. Then I was transferred to Burns, Oregon, in August 1961, where I was District Manager until 1966. I was transferred to Elko, Nevada, where I was District Manager there and served for 6 years.

In June 1972, I was transferred to the Washington office to serve in the Lands Division. I served as natural resource specialist in the Washington office from 1972 until October 1975. I was then transferred back to Cedar City. Bill Leavell called me and told me they had reorganized the districts in Utah and made about half as many districts as there used to be. They wanted me to come as an assistant to Morgan Jensen here in the Cedar City District. I had wanted to get back into the field away from Washington, so I accepted that and came to Cedar City where I served until January 3, 1986, when I retired. Since then I have lived here in Cedar City. During the period I was with the Bureau I served as a District Manager for 20 years in 3 states.

I was always active in the Society. I was active in the Utah Section while I was here. While in Nevada and the Northwest sections, I helped with the summer camps for the young boys, and helped teach some of their classes. While in Nevada, I was president of the Nevada Section. It was during that time that the name of the Society was changed. It started in Utah and Nevada. The fellow that followed Seler Hutchins on the Desert Range Experiment Station made the recommendation that we change the name to the Society for Range Management. That was in the late 1960s or early 1970s, the year I was president, that the change was made. The resolution went on to the main society and was approved.

I think the SRM is a very good organization for the professional people. I think it has been a good organization for the ranchers, too. There have been many that have been a very important part of the Society. It has been great to have not only the professional people, but also these ranch people that have been a part of it. It has been good for the professionals and ranchers to get together and exchange views and ideas. The Society has done a lot of good for the profession of range management, both for those who were ranchers and those in government agencies and in other positions. I felt real good about it, as a member myself, and in the meetings I attended in the different sections and in the national meetings. There is a lot of good that comes out of the exchange of ideas and learning what other people have done. One thing comes to mind, and that is Gus Hormay. Some people didn't agree with him, but I learned a lot from him. In my opinion, the principles he taught were important to range management. I felt what we were able to do because of the principles he taught really improved the profession. It helped us understand the principles that we need to follow to improve ranges and take care of them and to use the livestock properly on them. There has been a lot of improvement in range management. I saw it through my career even though things changed a lot and we got a lot more uses on the land through the years. Range management continued to be an important use, though it has not been recognized nationally as it should have been. I feel that with a little bit of money that was spent by the government in other places, we could have used that to improve management on the public lands more than we have.

I did see a lot of improvement. In 1952, I went to the Squaw Butte Station. For several years, the Bureau selected people to go to Squaw Butte each year to spend a week or two there just to exchange ideas and see what the Squaw Butte Experiment Range had done. There they had experiments showing what management could do over nature. That really impressed me. I have seen it done a lot on the range since. Through proper management, we can improve the ranges. We can improve on what nature can do, if we just do it properly. In my opinion, doing some artificial improvement of the ranges was good, because it gave us opportunities to seed some areas, which would give us some places to put livestock early in the spring before the native range was ready. I feel we really improved management a lot using some artificial improvements as well as natural improvement through livestock grazing. But, just through proper livestock grazing we can improve the ranges a lot. I have seen that in every state I worked in: Utah, Nevada, and Oregon. There has been a lot of improvement through management, as well as in some cases using artificial improvement to help get a better management system on the range. 
I think that it is good for all the people, the ranchers as well as the professionals coming into the government agencies, to be a part of this organization. You get with the people that have a lot of experience, and have seen things change, and they know what will work and what won't work. You learn a lot from rubbing shoulders with those people and getting to these meetings and finding out what these people are doing. It's just a wonderful thing.

I have been a member of the Society up to just last year. I was a charter member. I was there when it was organized. I have been there through the years and it is a good thing. I would hate to see it not continue, because it is a good organization. All the members can learn a lot by becoming active and participating in it.

\section{SRM Charter Member - John Forsman}

Editor's Note: These are John's remarks transmitted to Tom Bedell in March 2003. There was no oral interview. John can be reached at 4045 NW 190th, Portland, OR 97229, (503)645-2808.

In 1947-1948, when the ASRM was organized, I was a District Ranger on the Lewis and Clark National Forest in

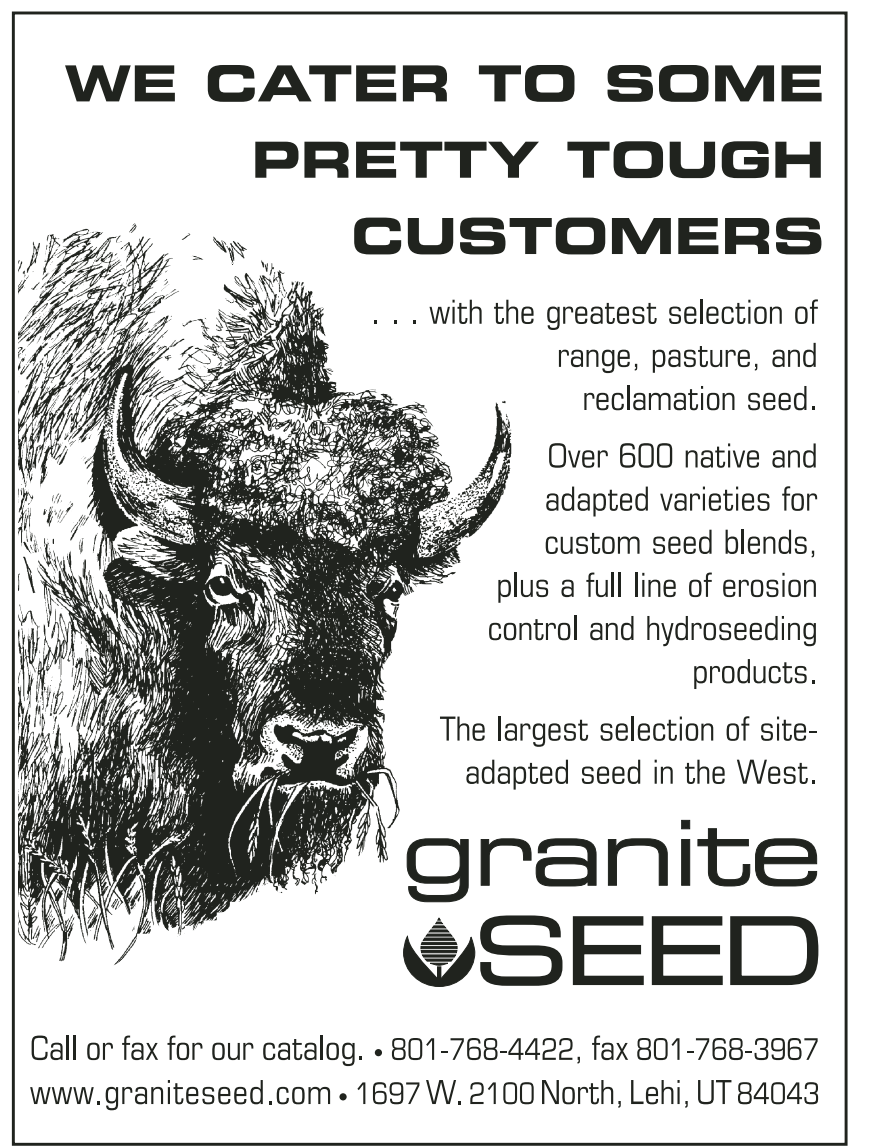

eastern Montana. Livestock grazing was the principal use on the district at that time.

I was raised on my Dad's cattle ranch in eastern Montana so I had an early interest in range and livestock. However, with the drought and depression in the 1930s, ranching was not a good choice for the future. I left the ranch in 1935 and enrolled in the University of Montana Forestry School majoring in range management. I worked summers for the Forest Service.

In 1945-1946 I worked for Tom Lommasson, who headed Range Surveys and Plans in the Forest Service regional office in Missoula. Tom led the effort in our region to organize the American Society of Range Management. I joined and have retained my membership.

The 1st national meeting of ASRM that I attended was in Boise, Idaho. I believe it was the 2nd meeting of the organization. I don't recall the program but I do remember the snowstorm that required an extra day for Lommasson, Forest Supervisor Fred Leftwich, and myself to return home.

I enjoyed my years with the Forest Service. I was a summer employee on ranger districts in northern Idaho and western Montana from 1936 until 1942. During 1943-1945 I was a navigator and flew combat with the Eighth Air Force from England bombing Germany. I spent 1945-1946 in the regional office in Missoula, Montana, on range inventories and 1947-1953 as District Ranger on the Lewis and Clark National Forest in eastern Montana. During 1954-1963 I was assistant and then Forest Supervisor on the Custer National Forest and Grasslands in southeastern Montana and North and South Dakota. Beginning in $1963 \mathrm{I}$ spent 31/2 years in the Washington office, Division of Range Management, and my final 10 years as Assistant Regional Forester for Range and Wildlife Management, headquartered in Portland, Oregon. I retired in 1976.

I have always been proud that I am a member of SRM. However, as I think back over the years, except for attending meetings and encouraging others to join, I have done little to benefit the Society. I have never held an office or been a committee member. It's well that others did better to make SRM the good organization it became.

I'm an old guy who, except for dealing in saddle horses, has not been active in range matters for several years. The last national meeting I attended was nearly 10 years ago in Boise. I am not going to try and judge today's range profession. It was great as I lived it and I would encourage young folks to give it a try if it is their 1st choice, and join SRM.

Tom Bedell is a member and former chairman of the SRM History Committee and a member of the Pacific Northwest Section living in Philomath, Oregon. 